\title{
Spatial Mapping of Soil Depth, Coarse Fragments and Textural Classes of Tamil Nadu Using Digital Soil Mapping Approach
}

\section{B Kalaiselvi ( $\square$ kalaimitra15@gmail.com )}

ICAR-National Bureau of Soil Survey and Land Use Planning https://orcid.org/0000-0002-1452-7255

\section{S. Dharumarajan}

ICAR-National Bureau of Soil Survey and Land Use Planning

\section{Lalitha}

ICAR-National Bureau of Soil Survey and Land Use Planning

\section{R. Srinivasan}

ICAR-National Bureau of Soil Survey and Land Use Planning

\section{R. Vasundhara}

ICAR-National Bureau of Soil Survey and Land Use Planning

\section{Amar Suputhra}

ICAR-National Bureau of Soil Survey and Land Use Planning

\section{Rajendra Hegde}

ICAR-National Bureau of Soil Survey and Land Use Planning

\section{Research Article}

Keywords: Spatial distribution, digital soil mapping, environmental covariates, soil properties, random forest model.

Posted Date: June 16th, 2021

DOl: https://doi.org/10.21203/rs.3.rs-596172/v1

License: (a) (1) This work is licensed under a Creative Commons Attribution 4.0 International License. Read Full License 
Spatial mapping of soil depth, coarse fragments and textural classes of Tamil Nadu using Digital soil mapping approach Kalaiselvi, B*., S. Dharumarajan, M. Lalitha, R. Srinivasan, R. Vasundhara, Amar Suputhra and Rajendra Hegde

Kalaiselvi B*, Scientist

S. Dharumarajan, Senior scientist

M. Lalitha, Scientist

R. Srinivasan, Scientist

R. Vasundhara, Scientist

Amar Suputhra, Young Profession II

Rajendra Hegde, Principal Scientist

ICAR-National Bureau of Soil Survey and Land Use Planning, Regional Centre, Hebbal, Bangalore, Karnataka, India

*Corresponding author: kalaimitra15@gmail.com

Orcid ID: 0000-0002-1452-7255

\section{Abstract}

Knowledge on spatial distribution of soil depth, coarse fragments and texture are crucial for land resource management and environmental soil modeling. Digital soil mapping approach helps in prediction of spatial soil information by establishing the relationship between soil and environmental covariates. In the present study, we assessed spatial 
23 distribution of soil depth, coarse fragments (CF) and soil textural classes over $0.13 \mathrm{M} \mathrm{sq.km}$

24 area of Tamil Nadu state. About 2100 samples were used for the prediction of soil 25 properties using random forest model (RF). Out of which, 80 per cent samples were used 26 for training and 20 percent samples were used for testing. Different environmental 27 covariates such as digital elevation model outputs, landsat data and bioclimatic variables were related to predict the soil properties. The predicted soil depth and CF ranged from 46-

$29200 \mathrm{~cm}$ and 1-42 per cent respectively. The RF model performed well by explaining the variability $\left(\mathrm{R}^{2}\right)$ of $43 \%$ for soil depth and $21 \%$ for coarse fragments with RMSE of $38 \mathrm{~cm}$

31 and 13\%, respectively. The RF classifier classified the soil textural classes with $64 \%$ overall

32 accuracy and 43\% kappa index. Variable importance ranking of Random forest model

33 showed that elevation, MrVBF are the important predictors used for prediction of soil

34 depth and CF, whereas remote sensing vegetation indices such as NDVI, EVI were acted as 35 primary variable for prediction of soil textural classes. In this study, $250 \mathrm{~m}$ resolution 36 detailed soil depth, $\mathrm{CF}$ and textural class maps were prepared which will be useful for 37 different environmental modeling and proper agricultural management purposes.

Keywords: Spatial distribution, digital soil mapping, environmental covariates, soil 39 properties, random forest model.

\section{Declarations}

41 Conflicts of interest/Competing interests: The authors declare that they have no

42 potential competing financial interests or personal relationships that could have appeared 43 to influence the work reported in this paper. 
44 Availability of data and material: The data that utilized for the study available from the 45 corresponding-author upon reasonable request.

46

47

48 
Spatial mapping of soil depth, coarse fragments and textural classes of Tamil Nadu

using Digital soil mapping approach

Kalaiselvi, B*., S. Dharumarajan, M. Lalitha, R. Srinivasan, R. Vasundhara, Amar Suputhra and

Rajendra Hegde

*Corresponding author: kalaimitra15@gmail.com

ICAR-National Bureau of Soil Survey and Land Use Planning, Regional Centre, Hebbal, Bangalore,

Abstract

57 Knowledge on spatial distribution of soil depth, coarse fragments and texture are crucial for land resource management and environmental soil modeling. Digital soil mapping approach helps in prediction of spatial soil information by establishing the relationship between soil and environmental covariates. In the present study, we assessed spatial distribution of soil depth, coarse fragments (CF) and soil textural classes over $0.13 \mathrm{M} \mathrm{sq.km}$ area of Tamil Nadu state. About 2100 samples were used for the prediction of soil properties using random forest model (RF). Out of which, 80 per cent samples were used for training and 20 percent samples were used for testing. Different environmental covariates such as digital elevation model outputs, landsat data and bioclimatic variables were related to predict the soil properties. The predicted soil depth and CF ranged from 46-

$67200 \mathrm{~cm}$ and 1-42 per cent respectively. The RF model performed well by explaining the variability $\left(\mathrm{R}^{2}\right)$ of $43 \%$ for soil depth and $21 \%$ for coarse fragments with RMSE of $38 \mathrm{~cm}$ and 13\%, respectively. The RF classifier classified the soil textural classes with $64 \%$ overall accuracy and 43\% kappa index. Variable importance ranking of Random Forest model

71 showed that elevation, MrVBF are the important predictors used for prediction of soil 
72 depth and CF, whereas remote sensing vegetation indices such as NDVI, EVI were acted as

73 primary variable for prediction of soil textural classes. In this study, $250 \mathrm{~m}$ resolution

74 detailed soil depth, $\mathrm{CF}$ and textural class maps were prepared which will be useful for

75 different environmental modeling and proper agricultural management purposes.

76 Keywords: Spatial distribution, digital soil mapping, environmental covariates, soil 77 properties, random forest model.

78 


\section{Introduction}

With increasing need for site-specific management in agriculture, the planners and researchers require spatially continuous soil information at higher resolution for better representation, resource assessment, spatial crop planning, land management and effective

83 policy making at regional and national level (McBratney et al. 2003). Spatial pattern of soil 84 depth influences soil moisture, plant available water content, nutrient capacity, runoff 85 generation (Gribb et al. 2009) and biological productivity (Gessler et al. 1995). Similarly, soil texture plays a key role in nutrient retention (Kettler et al. 2001), soil aeration and

87 porosity, soil aggregation and structure development (Carrizo 2015), soil organic carbon and soil quality (Kong et al. 2009), soil water transportation, soil degradation (Hillel 1980) 89 and soil productivity (Katerji \& Mastrorilli 2009). These soil properties are also act as important criteria in grouping the soil series for similar management purpose, land 91 suitability classes (Thompson et al. 2012) and involve in soil taxonomic classifications (Soil 92 Survey Staff 2014). Assessing spatial distribution of soil depth and coarse fragments is 93 laborious, difficult to measure practically as they are highly variable spatially (Wilding 94 1985). 100 101 97 et al. 2002) using the interrelationship between environmental covariates (DEM, climatic parameters, remote sensing imageries) (McBratney et al. 2003) and legacy soil information

99 (Akpa et al. 2014) through numerical, statistical and geostatistical models (Minasny and

Need for spatially seamless soil information dealt by prediction of soil properties by the concept of digital soil mapping which predicts the dependent soil properties (Florinsky McBratney 2016). It takes the advantage of ability to produce uncertainty and able to update when new data collected (Lagacherie and McBratney 2007). Spatial patterns in soil 
102 properties (soil depth, CF and texture) are resultant of complex interactions of different 103 factors such as geomorphic positions, topography, parent material, climate, weathering 104 rate, vegetation cover, lithology (Kuriakose et al. 2009), biological, chemical and physical 105 processes (Jenny 1941; Odeh et al. 1991). Thus, the environmental covariates related with 106 soil development selected for establishing the DSM models such as legacy soil data (S), 107 climatic information (C), Vegetation/landuse (0), derivatives of digital elevation models 108 (R), lithology (P) and geographic co-ordinates (N) (Minasny and McBratney 2016).

Tsai et al. (2001) used linear soil landscape regression model to map soil depth in 110 Taiwan and estimated the spatial solumn thickness with RMSE of $16.13 \mathrm{~cm}$. Tesfa et al. 111 (2009) developed statistical models for prediction of soil depth over complex terrain in 112 DCE watershed, USA (28 sq.km of 819 sub-watersheds) and found that with increasing 113 complexity of variabilities, RF outperforms as it is robust against overfitting. Kuriakose et 114 al. (2009) predicted soil depth with maximum capturable variability of 52\% $\left(\mathrm{R}^{2}\right)$ in part of 115 Western ghats, Kerala. Mehnatkesh et al. (2013) identified the relationship between soil 116 depth and topographic variables (slope, WI, catchment area and sediment transport index) 117 using MLR and explained 76\% total variability of soil depth. Bonfatti et al. (2016) used 118 multilinear regression model in Southern Brazil (8118 ha) and predicted soil depth with $\mathrm{R}^{2}$, 119 RMSE and CCC of $0.43,34.8 \mathrm{~cm}$ and 0.59 respectively. Lacoste et al. (2014) investigated soil 120 depth for a region in France of approximately 5,40,000 $\mathrm{km}^{2}$ and predicted the soil depth 121 with $\mathrm{R}^{2}$ and RMSE values between $50-58 \%$ and $35-39 \mathrm{~cm}$. Vaysse and Lagacherie (2017) 122 attempted to predict soil depth of Languedoc-Roussillon region, France and could capture 123 the maximum variability of $\mathrm{R}^{2}=23 \%$ with RMSE of $34 \mathrm{~cm}$. In India, Dharumarajan et al. 
124 (2020a) prepared 250 m resolution soil depth map of Karnataka using Regression kriging and QRF model which could explain maximum variability of $30 \%\left(\mathrm{R}^{2}\right)$ and $34 \mathrm{~cm}$ (RMSE).

Mosleh et al. (2016) used different Machine learning techniques (ANN, BRT, GLM and MLR) and found CF with $0.07 \mathrm{R}^{2}$ with RMSE of 3.2-3.7 which had high variability about 260\%. Similarly, Vaysse and Lagacherie (2015) evaluated simulation models, RFM and kriging approaches to coarse fragments and could capture only $4 \%$ variability of coarse fragments. Nussbaum et al. (2018) found that RF model performed better in prediction of soil gravel content with minimal RMSE of $2.64 \%$.

Few studies have been conducted in India to map soil textural classes either through prediction of sand, silt and clay particle size fractions (PSF) (Mitran et al. 2018; Dharumarajan et al. 2020) or categorical classes (Dharumarajan et al. 2020b). Many researches focused on PSF prediction for hydrological modelling, SOC stock estimation and textural class mapping using textural triangles (Akpa et al. 2014; Chagas et al. 2016; Mehrabi-Gohari et al. 2019; Zeraatpisheh et al. 2019; Dharumarajan et al. 2020b). RF classifier algorithms outperformed in classification of soil taxonomic classes (Silva et al. 2019; Boroujeni et al. 2020), parent material (Heung et al. 2014), land suitability (Senagi et al. 2017) etc. Lie $\beta$ et al. (2012) found the maximum efficacy of RF model over Regression Tree in PSF prediction (30-40\% R²). Vaysse and Lagacherie (2015) predicted PSF using RF with $33-35 \% \mathrm{R}^{2}$ of sand, $31-35 \% \mathrm{R}^{2}$ of clay and $23-29 \% \mathrm{R}^{2}$ of silt content. Camera et al. (2017) reported that random forest classifier was more remarkable than MLR in soil texture classification. Zhang et al. (2020) compared five different models for the classification of soil texture class and found that random forest classifier performed significantly with overall accuracy of 65 per cent and profound improvement in kappa 
147 index of 21 per cent. Abraham et al. (2020) predicted soil particle size fractions using the 148 Random Forest algorithm to get soil textural classes and got the highest overall accuracy of 14984.70 percent compared to other models with kappa index of 55-70 percent.

After inception of GlobalSoilMap project, many researches focused on spatial 151 mapping of soil properties worldwide (Arrouays et al. 2014). In India, very limited 152 attempts only made in digital soil mapping (Sreenivas et al. 2016; Dharumarajan et al. 1532017,2019 \& 2020; Reddy et al. 2021). Accurate prediction of soil properties would help in 154 crop productivity and comprehensive land management especially ecological, crop 155 suitability and hydrological modelling. With this context, an exploratory study was 156 conducted to map soil depth, CF and texture of Tamil Nadu experiencing semiarid climate 157 using Random Forest model techniques.

159 Materials and Methods:

\section{Study Area}

Tamil Nadu is the south most state in India with 130058 sq.km area extended 162 between $8^{\circ} 5^{\prime}$ and $13^{\circ} 35^{\prime} \mathrm{N}$ and $76^{\circ} 15^{\prime}$ and $80^{\circ} 12^{\prime} \mathrm{E}$ which accounts for 3.96 percent of the 163 total geographical area (TGA) of the country (Fig.1). Tamil Nadu state has been divided into 164 three physiographic units namely South deccan plateau (uplands), Hill ranges and Coastal 165 Plains (Inland plain and Marine plain) (Natarajan et al. 1997). The geological formations of 166 study area are dominant with Precambrian granitic, pink gneiss and charnockite followed 167 by Pleistocenic alluvium and in someparts Pliocene sandstone. Tamil Nadu comes under 168 semiarid agro-eco region which receives bi-model rainfall ie., $48 \%$ from NEM and 32\% 169 from SWM. Mean minimum and maximum temperatures ranged between $21.6^{\circ} \mathrm{C}-31.8^{\circ} \mathrm{C}$. 
171 (6\%) and Ultisols (1\%) and negligible areas of Mollisols (Natarajan et al. 1997). Major 172 crops being cultivated are Paddy, Pulses, Groundnut, Sugarcane, Cotton, Coconut, fruit and 173 vegetable crops.

174

175

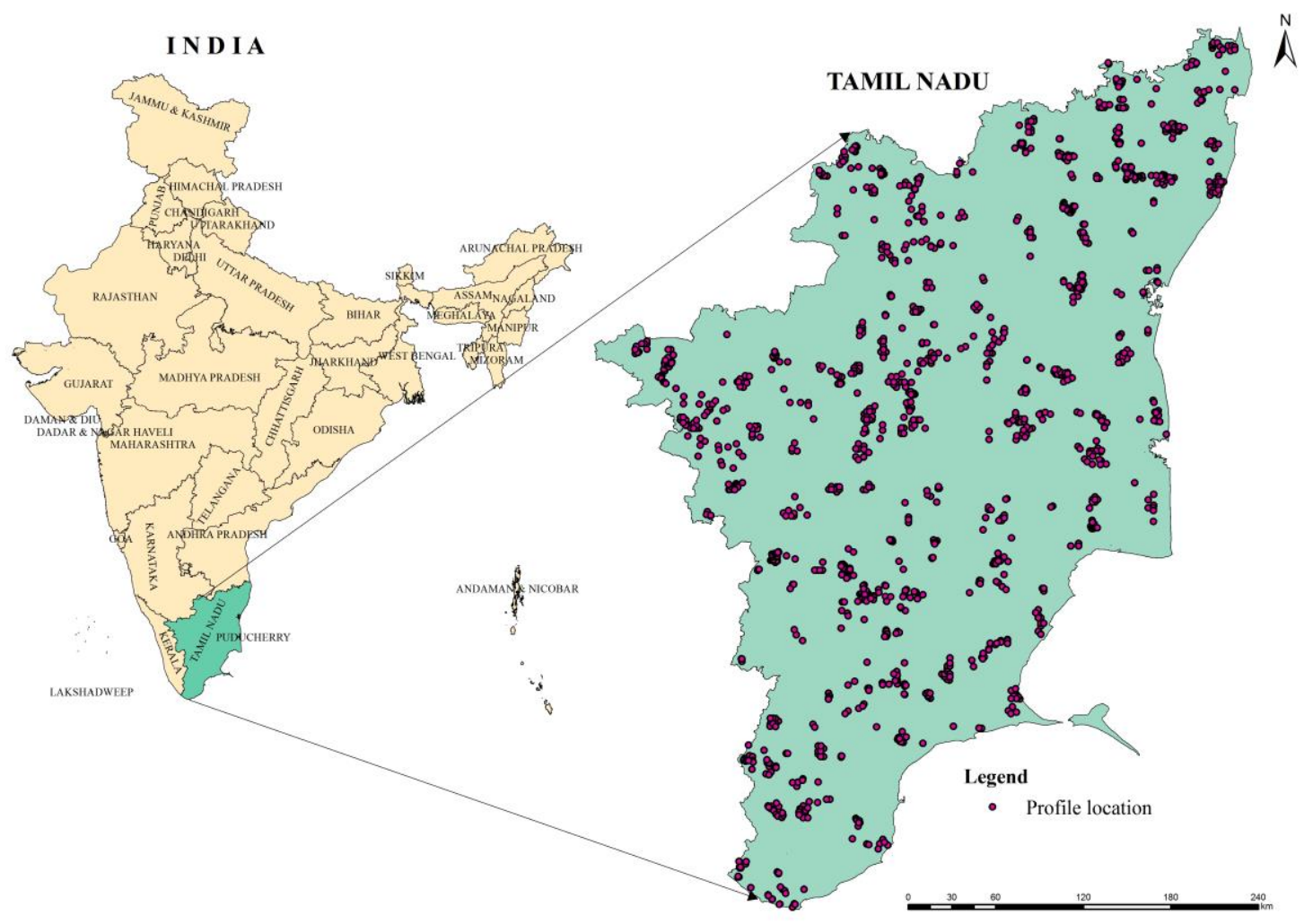

\section{Fig.1. Study area with profile locations}

\section{Sampling Methodology}

Soils studied during soil resource mapping (SRM) of Tamil Nadu at 1:250,000 scale (1989-1999) and soils studied by Tamil Nadu state soil survey department and other ICAR-NBSS\&LUP projects are collected and organized for mapping of soil depth, coarse fragments and texture in Tamil Nadu. The geospatial information of the soils studied during soil resource mapping were limited with degree-minutes which were again assigned with 
182 specific coordinate pertained to the village information. A total of 2119 soil profiles were 183 used for depth prediction study after removing the outliers whereas 2105 surface soil 184 samples were used for coarse fragments and texture class mapping. While using the soil textural classes for spatial mapping, neighbouring soil textural classes are merged into 186 broader classes such as clay and sandy clay into clay (C), clay loam and sandy clay loam in 187 to loam (L) and loamy sand and sandy loam into sandy (S) textural classes based on the 188 earlier studies proven that more number of soil classes with less frequencies may result in 189 significant decrease in prediction accuracy (Lagacharie et al. 2019; Boroujeni et al. 2020).

190 Environmental co-variates:

Digital elevation model (DEM) of $30 \mathrm{~m}$ resolution obtained from shuttle radar 192 topography mission (SRTM) was used to derive different topographic derivatives such as, 193 elevation, slope, aspect, topographic position index (TPI), topographic wetness Index 194 (TWI), LS factor, Multi-resolution Index of Valley Bottom Flatness (MrVBF) and multi195 resolution ridge top flatness (MrRTF) as topography is the main soil forming factor in semi196 arid regions (Mehnatkesh et al. 2013). Remote sensing variables such as, LISS III band data 197 (1-4), normalized difference vegetation index (NDVI) and enhanced vegetation index (EVI) 198 were also used to relate with the soil properties. Annual mean rainfall, maximum mean 199 temperature (Tmax) and minimum mean temperature (Tmin) are used to represent 200 climate in the models. The bio-climatic variables (19) such as isothermality, precipitation of 201 driest month, precipitation of wettest month, precipitation seasonality and mean diurnal 202 range were also included as environmental covariates for soil properties prediction. 203 Correlation between the soil properties and the environmental co-variates was analyzed 
204 using pearson correlation coefficient analysis with confidence level of $95 \%$. Soil properties 205 prediction methodology presented in Fig. 2.

Table 1. Different covariates used in the model

\begin{tabular}{|c|c|c|}
\hline Predictor & Source & Resolution \\
\hline Elevation (m) & SRTM DEM & $30 \mathrm{~m}$ \\
\hline Slope (\%) & SRTM DEM & $30 \mathrm{~m}$ \\
\hline Aspect & SRTM DEM & $30 \mathrm{~m}$ \\
\hline TPI & SRTM DEM & $30 \mathrm{~m}$ \\
\hline TWI & SRTM DEM & $30 \mathrm{~m}$ \\
\hline Plan curvature & SRTM DEM & $30 \mathrm{~m}$ \\
\hline LS-factor & SRTM DEM & $30 \mathrm{~m}$ \\
\hline MrVBF & SRTM DEM & $30 \mathrm{~m}$ \\
\hline MrRTF & SRTM DEM & $30 \mathrm{~m}$ \\
\hline NDVI & MOD13Q1(2011-2015) & $250 \mathrm{~m}$ \\
\hline EVI & MOD13Q1(2011-2015) & days \\
\hline LISS-III & 4 bands & $26 \mathrm{~m}$ \\
\hline Precipitation (mm) & WorldClim2 & $10 \mathrm{~min}$ \\
\hline $\begin{array}{l}\text { Minimum temperature } \\
(\mathrm{Tmin})\left({ }^{\circ} \mathrm{C}\right)\end{array}$ & WorldClim2 & $10 \mathrm{~min}$ \\
\hline $\begin{array}{l}\text { Maximum temperature } \\
(\operatorname{Tmax})\left({ }^{\circ} \mathrm{C}\right)\end{array}$ & WorldClim2 & $10 \mathrm{~min}$ \\
\hline Isothermality & WorldClim2 & $10 \mathrm{~min}$ \\
\hline $\begin{array}{l}\text { Precipitation of driest } \\
\text { month (mm) }\end{array}$ & WorldClim2 & $10 \mathrm{~min}$ \\
\hline $\begin{array}{l}\text { Precipitation of wettest } \\
\text { month (mm) }\end{array}$ & WorldClim2 & $10 \mathrm{~min}$ \\
\hline $\begin{array}{l}\text { Precipitation } \\
\text { seasonality }\end{array}$ & WorldClim2 & $10 \mathrm{~min}$ \\
\hline
\end{tabular}




\begin{tabular}{|ll|l|l|}
\hline $\begin{array}{l}\text { Mean diurnal range } \\
\left({ }^{\circ} \mathrm{C}\right)\end{array}$ & WorldClim2 & $10 \mathrm{~min}$ \\
\hline
\end{tabular}

\section{Random forest model:}

Random Forest model (RFM) is an ensemble of decision trees which considers each

211 individual tree's decision to predict and classify the soil properties in addition, it can rank

212 the variables based on their significance in prediction (Breiman 2001). RF model tuned

213 depending on the number of trees to be grown (ntree), number of variables used to split

214 the nodes (mtry) and minimum number of samples at each node (nmin). Random forest

215 model is insensitive to noisy, huge and missing dataset which can handle both quantitative

216 and categorical dataset by regression and classification algorithm (Dharumarajan et al.

217 2017). Statistical software $\mathrm{R}$ of randomForest package (Version $\mathrm{R}$ 4.0.5) was used to

218 establish the relationship between environmental variables (R Development Core Team

219 2012).

220 Model prediction performance:

221 For calibration of the prediction model, $80 \%$ of soil depth and CF datasets were used

222 and 20\% remaining dataset was used for validation dataset and based on the 50 iterations

223 the performance of the models was evaluated. Model prediction performance was

224 evaluated using coefficient of determination $\left(\mathrm{R}^{2}\right)$, Lin's concordance correlation coefficient

225 (CCC), root mean square error (RMSE) and mean error (bias) of the validation datasets

226 (Mitran et al., 2018). The value of $\mathrm{R}^{2}$ and CCC nearing 1 and RMSE to 0, indicates the good

227 prediction performance of the model (Dharumarajan et al. 2017).

$$
\mathrm{R} 2=1-\frac{\sum_{i=1}^{n}(p i-o i)^{2}}{\sum_{i=1}^{n}(o i-\overline{o l})^{2}}
$$




$$
\mathrm{M} E=\frac{1}{n} \sum_{i=1}^{n}(o i-p i)
$$

$$
\mathrm{R} M S E=\sqrt{\frac{1}{n} \sum_{i=1}^{n}(o i-p i)^{2}}
$$

232 Where, pi and oi are predicted and observed values, pi and oi are means of predicted and 233 observed values.

\section{Lin's Concordance correlation coefficient}

$$
\operatorname{CCC}\left(\rho_{c}\right)=\frac{2 \rho \sigma_{0} \sigma_{p}}{\sigma_{0}^{2}+\sigma_{p}^{2}+\left(\mu_{0}-\mu_{p}\right)^{2}}
$$

237 corresponding variance $\rho$ is Pearson correlation coefficient between observed and 238 predicted values.

239

\section{Performance evaluation of RF classifier algorithm:}

242 kappa index.

Overall accuracy:

246 shown as below,

$$
O A=\sum_{i=1}^{n} \frac{X_{i i}}{N}
$$


248 Where $\mathrm{n}$ is the number of columns or rows of error matrix, Xii is the classes predicted 249 properly, and $\mathrm{N}$ is the total number of observations (Byrt et al. 1993).

\section{Kappa index:}

Kappa index is the degree to which classification outcome is superior than the

252 outcome of random classification (Cohen 1960). Kappa index $>0.80,0.4-0.8$ and $<0.4$

253 indicates the strong, moderate and poor agreements of classification, respectively 254 (Congalton and Green 1998).

255 Uncertainty analysis:

The lack of reality assurance in prediction is considered as uncertainty (Heuvelink, 257 2013) and its estimation along with prediction is important for assessing the risk in 258 decision making. The uncertainty of the prediction was quantified by computing upper 259 (95\% quantile) and lower confidence (5\% quantile) interval limits on the prediction map 260 (Viscarra Rossel et al. 2014) which indicates that 90\% of the time, an observed value will 261 fall with in this prediction interval (Malone et al. 2014). The uncertainty for classifier 262 algorithm is evaluated by error/confusion matrix (Boroujeni et al. 2020) which compares 263 the measured and predicted soil classes and checks whether the categorization is 264 satisfactory (Story and Congalton 1986). Confusion index/ error classification values vary 265 from 0 to 1 , of which larger values indicate higher uncertainty. 


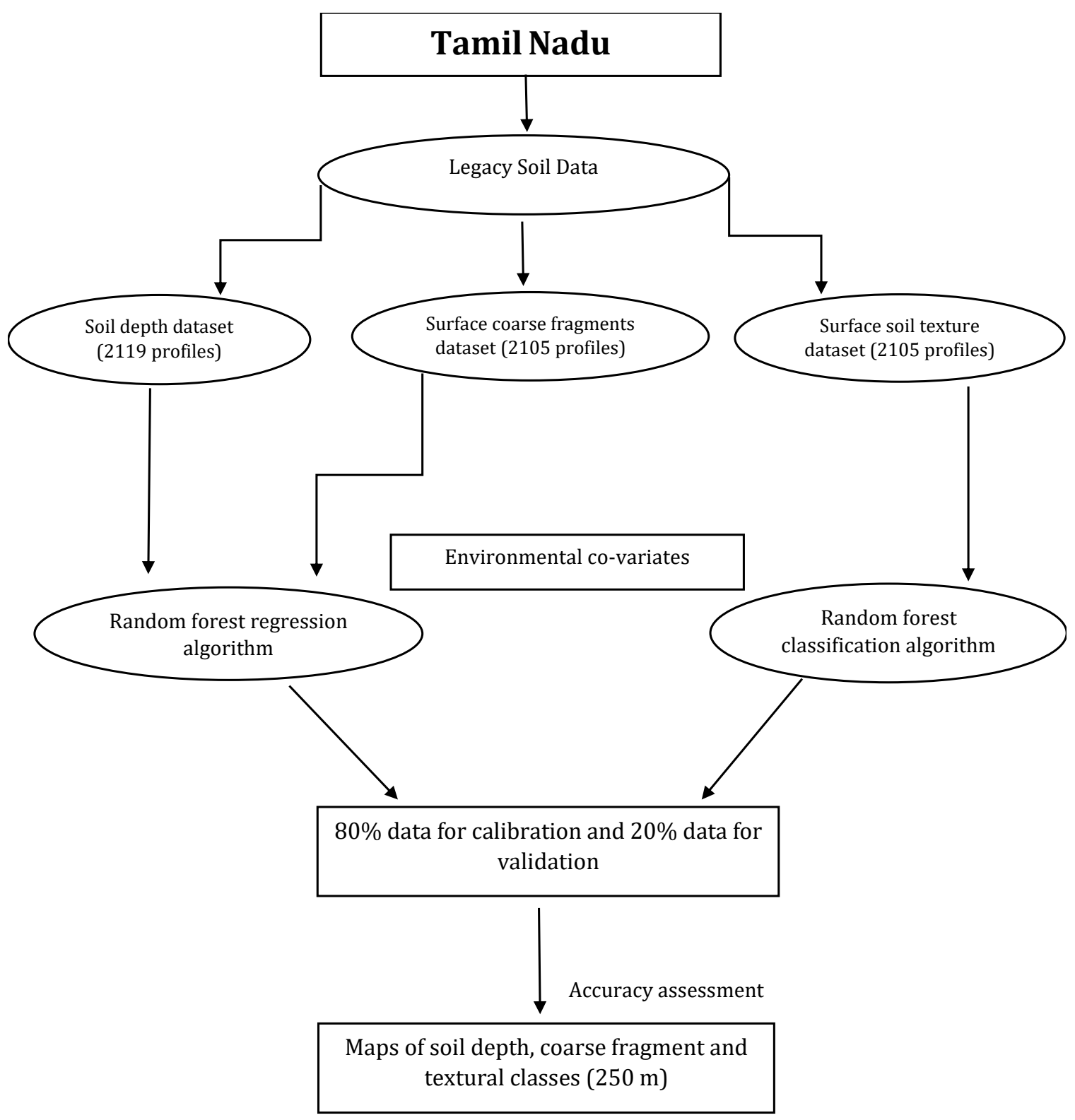

Fig. 2. Methodology Flow Chart 


\section{Result and Discussion:}

\section{Descriptive statistics:}

Summary statistics of soil depth and coarse fragments are given in Table. 2. Soil depth varied from 9-217 cm with mean of $119 \pm 51 \mathrm{~cm}$. Soil depth was skewed positively with negative kurtosis and the co-efficient of variation was 42.5 percent which indicates the high variability of soil depth in the study area. Similar results are in concordance with Kuriakose et al. (2009) and Dharumarajan et al. (2020a). Coarse fragments varied from non-gravelly $(<15 \%)$ to very gravelly $(80 \%)$ with positive skewness and kurtosis which shows the assymetrical distribution of CF. The very high variability (Wilding 1985) of coarse fragments (CV-135\%) was recorded due to differences in landscape, transportability of soil particles and geographical dissimilarity (Tola et al. 2017). The variability of soil properties might attributed to the variability in topography and soil formation (Grimm et al. 2008). Correlation analysis has registered significant relationship between soil depth and coarse fragments with environmental variables (Table. 3). Soil depths were positively correlated with MRRTF $\left(r=0.10^{* *}\right)$, MRVBF $\left(r=0.20^{* *}\right)$, precipitation $\left(\mathrm{r}=0.24^{* *}\right)$ and minimum temperature $(\mathrm{Tmin})\left(\mathrm{r}=0.15^{* *}\right)$. It was negatively correlated with elevation $\left(\mathrm{r}=-0.14^{* *}\right)$, TWI $\left(\mathrm{r}=-0.13^{* *}\right)$ and with satellite band data. In contrast to soil depth, coarse fragments shown significant positive relationship with elevation $\left(\mathrm{r}=0.06^{* *}\right)$, TWI $\left(r=0.13^{* *}\right)$ and band data and negative correlation with MRRTF $\left(r=-0.08^{* *}\right)$, MRVBF $\left(\mathrm{r}=-0.15^{* *}\right)$, maximum (Tmax) and minimum temperature (Tmin). With increasing slope and elevation, the soil depth and coarse fragments shown negative and positive relationship respectively due to erosional soil loss on slope gradients (Tsai et al. 2001; Florinsky et al. 2002). This correlation study shows indirectly that coarse fragments of 
292 valley (alluvial plains) are mere neglible as the depositional soils are devoid of coarse

293 fragments (Dharumarajan et al. 2021). Soil textural classes were recorded from 2105

294 surface samples in Tamil Nadu and classified into clay (464), loam (641) and sandy (1000)

295 textural classes. Among the studied soils, predominant soil textural class is sandy soil that

296 occupies about $48 \%$ followed by loamy soils (31\%).

297 Performance of RF prediction model:

298 The performance of the model was evaluated with average performance over 50

299 iterations using the accuracy indicators like $\mathrm{R}^{2}$, RMSE and bias given in Table 4. The result

300 shown that the soil depth was predicted with the explained variability of $R^{2}=0.43 \pm 0.04$ and

301 RMSE of $38 \mathrm{~cm}$. The concordance value for the prediction was $0.612 \pm 0.03$ that confirms

302 that the moderately good performance of the model (Dharumarajan et al. 2017). The

303 performance of the Random Forest model was comparatively better than the QRF model

304 used in Karnataka soil depth mapping which could only explain $17 \%$ variability $\left(R^{2}\right)$

305 (Dharumarajan et al. 2020a). In African continent, Hengl et al. (2021) predicted soil depth

306 to bedrock suing $30 \mathrm{~m}$ resolution co-variates using 28054 sample data and predicted depth

307 with $0.43 \mathrm{R}^{2} ; 41.3 \mathrm{~cm}$ RMSE and $0.73 \mathrm{CCC}$ with ensemble of RF, XG boost, deep net, Cubist

308 and GLM net. The prediction of coarse fragments shown that the model could find the

309 variability of 21 per cent $\left(\mathrm{R}^{2}=0.21\right)$ with $13 \%$ RMSE. Compared to soil depth, the bias is

310 higher for coarse fragment prediction. The prediction of CF by RFM is quite low which

311 might be due to high terrain variability and minimal dataset of gravelly soils (Mosleh et al.

312 2016). Hengl et al. (2004) predicted coarse fragments using SVM with medium level of

313 validity. With regard to soil surface textural classification, the random forest classifier

314 classified the textural class with overall accuracy and kappa index of $63.8 \%$ and $41.5 \%$, 
315 respectively with confidence interval of $0.59-0.68$. This short range of prediction interval 316 indicates the better performance of RF classifier. The performance of RF model is similar to 317 Dharumarajan et al. (2020b) who mapped spatial and vertical (GlobalSoilMap depth specification) textural class map of Andhra Pradesh by predicting PSF and could classify 319 the textural classes with overall accuracy and kappa coefficient of 52-65\% and $42-47 \%$ 320 respectively. Similar results were obtained from soil textural classification using Landsat-5

321 TM images reported with over all accuracy of around 58-64\% (Dematte et al. 2016). Zhang 322 et al. 2020) signified the performance of RF in soil textural classification with profound 323 improvement in reduction of error with increased kappa index of 0.21 by comparing 5 324 different ML models. Boroujeni et al. (2020) classified WRB soil classes using RF model and 325 resulted with $0.73 \mathrm{OA}$ at first level with less confusion index. The mean of confusion matrix 326 obtained by running $50 \mathrm{RF}$ models given in Table 6. In which, only 187 soils only correctly 327 classified as clay out of 464 soil, similarly 275 soils only classified as loamy out of 641 . 328 Despite, about 60 per cent of the soils were classified to the correct class (Sandy texture). 329 The error matrix shows (Table 6) that the classification of sandy classes (error= 0.261 ) is 330 much better than other class (clay $=0.497$; loam $=0.464$ ) with respect to error estimates.

331 The results are in concordance with the previously documented studies that classes with 332 lower sampling frequencies were modeled less accurately (e.g., Lagacherie et al. 2019;

333 Boroujeni et al. 2020).

\section{Importance of variables:}

The variables that contribute substantial for prediction of soil properties are assessed by Random Forest model. Fig.3 shows the variable importance ranking of RFM for

337 prediction of soil depth, CF and textural classes. Derivatives of digital elevation models/ 
338 topographic variables such as elevation, MRVBF, MRRTF are the primary variables involves

339 in prediction of soil depth and coarse fragment contents (Adhikari et al. 2013; Lu et al.

340 2019). Some climatic (Tmax) and bioclimatic variables (bio_4) are also bestowed for

341 prediction of soil properties (Malone et al. 2020). Topographic variables were found to be

342 generally more important than the land cover variables in predicting soil depth for this

343 dataset (Tsai et al. 2001; Grimm et al. 2008). Complexity of the environmental variables

344 resulting in variable soil depth (Chan et al. 2019). Similarly, MRVBF and elevation are the

345 prime variables influencing the prediction of coarse fragments. For textural classification,

346 remote sensing indices such as NDVI, EVI, topographical variables (elevation, MRVBF,

347 MRRTF, TWI) (Mehrabi-Gohari et al. 2019) and climatic variables took part in classification

348 of soil textural classes (minimum temperature (Tmin) and Precipitation) (Akpa et al.

349 2014).

350 Soil prediction maps:

351 Summary statistics of the predicted soil properties given in Table 5. Predicted soil

352 depth and CF ranged between $90-195 \mathrm{~cm}$ and 0-40\% respectively. Skewness and kurtosis

353 of the predicted coarse fragments indicates the presence of extreme values which is

354 reflected in coefficient of variation (CV\%-142\%), whereas, the predicted soil depth did not

355 register much variability (CV\%-11.4\%). Predicted soil depth map (Fig. 4a) shows that the

356 depth ranged between 46 and $200 \mathrm{~cm}$ and the deeper soils occurring on western ghat

357 (western side) attributed to climate and vegetational influence on soil development

358 (Dharumarajan et al. 2020a) and valley bottom (eastern and south-eastern part) of Tamil

359 Nadu due to the deposition of soil particles from higher elevation to lower elevation

360 (Bonfatti et al. 2016). Spatial variability of soil depth attributed to parent material, 
361 relief/topography and climate (Shivaprasad et al. 1998). Rudiyanto et al. (2016) suggested

362 that improved sampling strategies and machine learning approaches can increase the 363 accuracy of soil depth prediction. Coarse fragments map varied with 1 to 42 per cent of CF 364 (Fig. 4c). Higher CF content was noticed in western and northwestern part of Tamil Nadu 365 (Western ghats and Tamil Nadu uplands). Contradict to depth distribution, CF recorded 366 high in uplands and low in alluvial/coastal plains owing to runoff losses of soil finer 367 particles. According to textural class map (Fig. 5), the Tamil Nadu surface soils are 368 dominated with sandy texture (Sandy loam and loamy sand), followed by clayey (clay, 369 sandy clay) and loamy soils (clay loam and sandy clay loam). Clayey soils distributed in 370 eastern and southern coastal part of Tamil Nadu, whereas, sandy soils distributed in 371 northern and central part of Tamil Nadu. Variation of textural classes shows the transition 372 of clay particles through fluvial movement from upland to lower elevation of eastern and 373 south eastern part of Tamil Nadu with high clayey soils (Dharumarajan et al. 2020b). 374 Coarser soil particles found in upper elevation than low lying areas due to the decreased 375 transportability of sand particles (Mashalaba et al. 2020). Uncertainty maps of soil depth (Fig. 4b) manifest that high uncertainty of soil depth 377 was noticed in lowland (coastal) and western ghats region which might be due to local 378 landscape variation. Whereas, the low uncertainty of soil depth was noticed in uplands 379 attributed to the similarity in the landscape and climate. The highest uncertainty of coarse 380 fragments (Fig. 4d) was observed in the Tamil Nadu uplands which might be due to high 381 elevation, erosional variability (Kalaiselvi et al. 2019) and granitic gneiss parent material 382 whereas, the lowest uncertainties were observed in the coastal and low lying lands 383 attributed to the non-gravelliness of depositional soils (Dharumarajan et al. 2021). 
384 Regardless, the predicted soil maps can help in assessing the physical constraints for crop 385 growth (Vagen et al. 2016), and used to find the suitable crops to cultivate, optimal 386 fertilizer and other management aspects.

387 Conclusion: were prepared using $\mathrm{RF}$ model. The result shown that the interrelationship between covariates could explain 43 and 21 per cent of soil depth and coarse fragments variability respectively. Terrain attributes such as elevation and MrVBF are the main predictors of soil 392 depth and CF, whereas, Remote sensing indices (NDVI and EVI) are the important 393 predictors of soil textural classes. Uncertainty map shows that Tamil Nadu upland soil has 394 high uncertainty of depth prediction than the coastal soils. Surface soil textural mapping 395 also acceptable with overall accuracy of $63.8 \%$. Faster run time and reliable prediction 396 performance of RF model helps in prediction and classification of soil properties. The 397 prediction performance could be improved by incorporating additional covariates such as 398 lithological data etc, increasing sampling density and stratification of dataset for different 399 landscape units.

400 Declarations

401 Conflicts of interest/Competing interests: The authors declare that they have no 402 potential competing financial interests or personal relationships that could have appeared 403 to influence the work reported in this paper.

404 Availability of data and material: The data that utilized for the study available from the 405 corresponding-author upon reasonable request. 
Table 2. Descriptive statistics of observed soil depth and CF

\begin{tabular}{|l|l|l|}
\hline Parameter & $\begin{array}{l}\text { Depth } \\
(\mathrm{cm})\end{array}$ & CF (\%) \\
\hline Mean & 119 & 11 \\
\hline Minimum & 9 & 0 \\
\hline Maximum & 217 & 80 \\
\hline Std. Dev & 50.78 & 15.0 \\
\hline Skewness & 0.02 & 1.80 \\
\hline Kurtosis & -1.09 & 3.09 \\
\hline CV (\%) & 42.5 & 135 \\
\hline
\end{tabular}

Table 3. Correlation analysis between covariates and soil properties

\begin{tabular}{|l|c|c|}
\hline \multirow{2}{*}{ Variables } & \multicolumn{2}{c|}{ Correlation co-efficient (R) } \\
\cline { 2 - 3 } & Soil depth & Coarse fragments \\
\hline Elevation & $-0.14^{* *}$ & $0.06^{* *}$ \\
\hline EVI & 0.02 & -0.00 \\
\hline NDVI & 0.01 & 0.02 \\
\hline TWI & $-0.13^{* *}$ & $0.13^{* *}$ \\
\hline LS_Factor & -0.04 & 0.00 \\
\hline MRRTF & $0.10^{* *}$ & $-0.08^{* *}$ \\
\hline MRVBF & $0.20^{* *}$ & $-0.15^{* *}$ \\
\hline Plan curvature & $0.05^{*}$ & -0.04 \\
\hline Slope & -0.01 & 0.01 \\
\hline TPI & -0.01 & 0.04 \\
\hline Aspect & 0.00 & -0.02 \\
\hline
\end{tabular}




\begin{tabular}{|l|c|c|}
\hline Prec & $0.24^{* *}$ & $-0.19^{* *}$ \\
\hline Minimum temperature (Tmin) & $0.15^{* *}$ & $-0.07^{* *}$ \\
\hline Maximum temperature (Tmax) & 0.00 & 0.02 \\
\hline bio_7 & $-0.24^{* *}$ & $0.14^{* *}$ \\
\hline bio_8 & 0.02 & 0.02 \\
\hline bio_6 & $0.16^{* *}$ & $-0.07^{* *}$ \\
\hline bio_5 & -0.01 & 0.03 \\
\hline bio_4 & $0.08^{* *}$ & $-0.06^{* *}$ \\
\hline bio_3 & $-0.20^{* *}$ & $0.12^{* *}$ \\
\hline bio_2 & $-0.43^{* *}$ & $0.25^{* *}$ \\
\hline bio_19 & $0.29^{* *}$ & $-0.23^{* *}$ \\
\hline bio_10 & $0.08^{* *}$ & -0.02 \\
\hline bio_11 & $0.07^{* *}$ & -0.01 \\
\hline bio_12 & $0.24^{* *}$ & $-0.20^{* *}$ \\
\hline bio_13 & $0.24^{* *}$ & $-0.20^{* *}$ \\
\hline bio_14 & $0.10^{* *}$ & $-0.08^{* *}$ \\
\hline bio_15 & $0.13^{* *}$ & $-0.11^{* *}$ \\
\hline bio_16 & $0.30^{* *}$ & $-0.25^{* *}$ \\
\hline bio_17 & $0.17^{* *}$ & $-0.13^{* *}$ \\
\hline bio_1 & $0.08^{* *}$ & -0.02 \\
\hline bio_18 & $-0.08^{* *}$ & 0.04 \\
\hline bio_9 & $0.06^{* *}$ & -0.01 \\
\hline b1_LISS $(0.52-0.59 \mu \mathrm{m})$ & $-0.19^{* *}$ & $0.11^{* *}$ \\
\hline b2_LISS $(0.62-0.68 \mu \mathrm{m})$ & $-0.12^{* *}$ & $0.07^{* *}$ \\
\hline b3_LISS $(0.77-0.86 \mu \mathrm{m})$ & $-0.04^{*}$ & 0.00 \\
\hline b4_LISS $(1.55-1.70 \mu \mathrm{m})$ & $-0.31^{* *}$ & $0.18^{* *}$ \\
\hline & & \\
\hline & & \\
\hline
\end{tabular}


Table 4. Performance of Random Forest model for prediction of soil properties

\begin{tabular}{|l|l|l|l|l|}
\hline Soil properties & $\mathrm{R}^{2}$ & Concordance C & RMSE & Mean error \\
\hline Soil depth (cm) & 0.43 & 0.61 & 38 & 0.19 \\
\hline Coarse fragments (\%) & 0.21 & 0.42 & 13 & 0.44 \\
\hline
\end{tabular}

411 


\begin{tabular}{|l|c|c|}
\hline Parameter & Depth & \\
\hline Mean & 148 & 2.5 \\
\hline Minimum & 90 & 0 \\
\hline Maximum & 195 & 40 \\
\hline Std. Dev & 16.8 & 3.5 \\
\hline Skewness & 0.01 & 1.66 \\
\hline Kurtosis & -0.31 & 4.16 \\
\hline CV (\%) & 11.4 & 142 \\
\hline
\end{tabular}

415

Table 6. Confusion matrix of Soil textural classification

\begin{tabular}{|l|l|c|c|c|c|}
\hline \multicolumn{2}{|c|}{} & \multicolumn{3}{c|}{ Observed } & Classification \\
\hline \multirow{2}{*}{} & Soil textural class & Clay soils & Loamy soils & Sandy soils & error \\
\cline { 2 - 6 } & Clay soils & 187 & 79 & 106 & 0.50 \\
\cline { 2 - 6 } & Loamy soils & 63 & 275 & 175 & 0.46 \\
\cline { 2 - 5 } & Sandy soils & 76 & 133 & 591 & 0.26 \\
\hline
\end{tabular}

417 


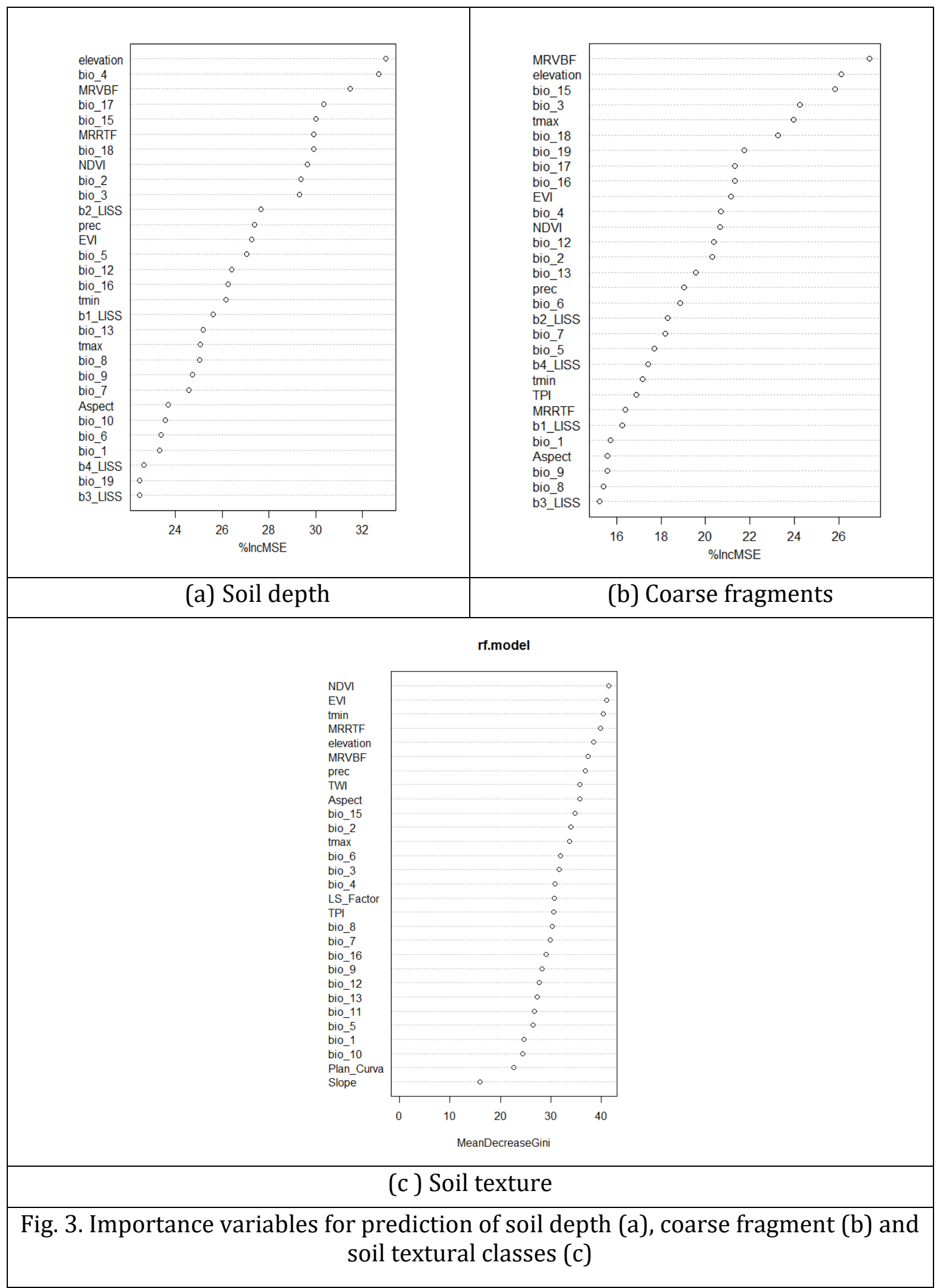




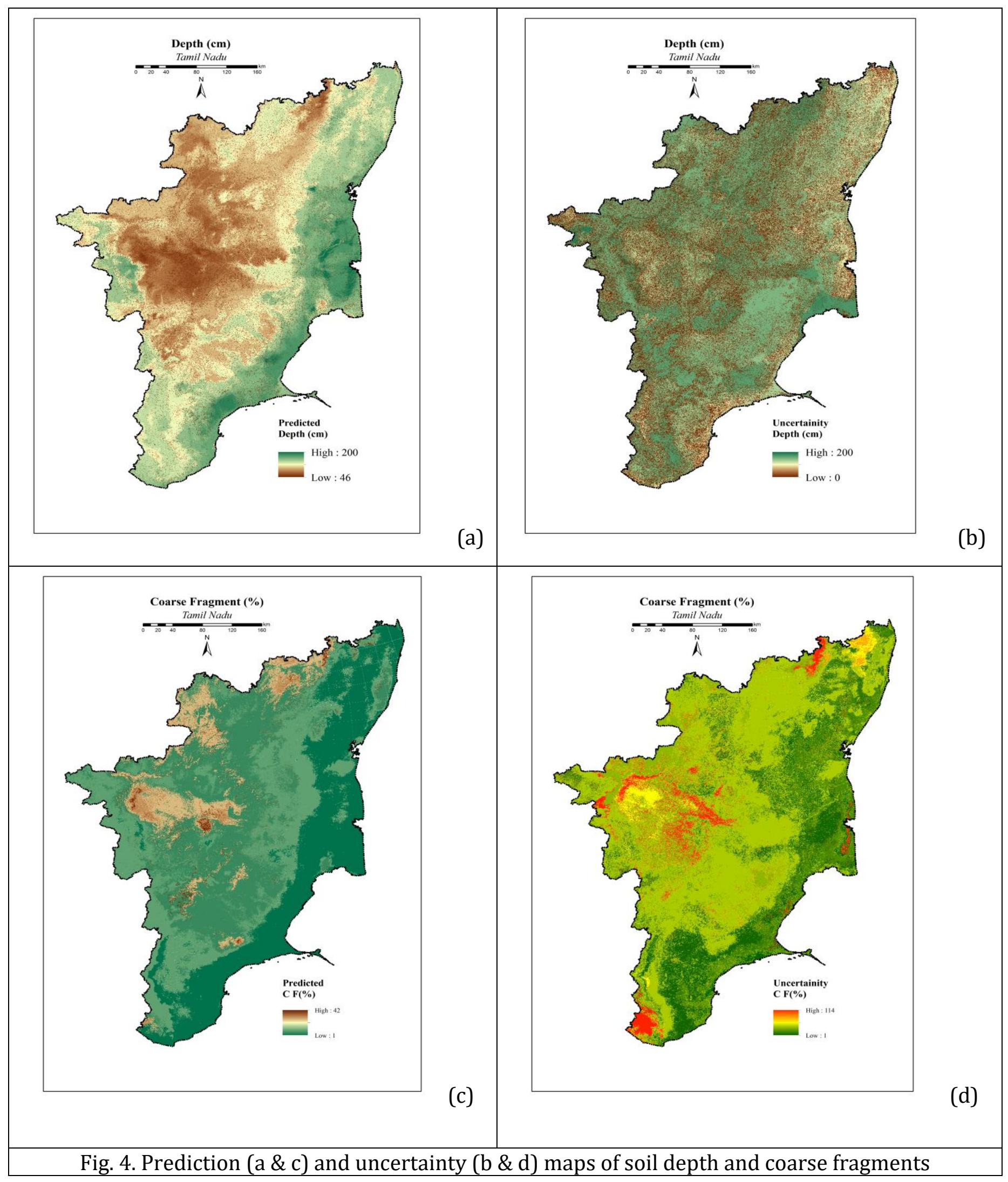




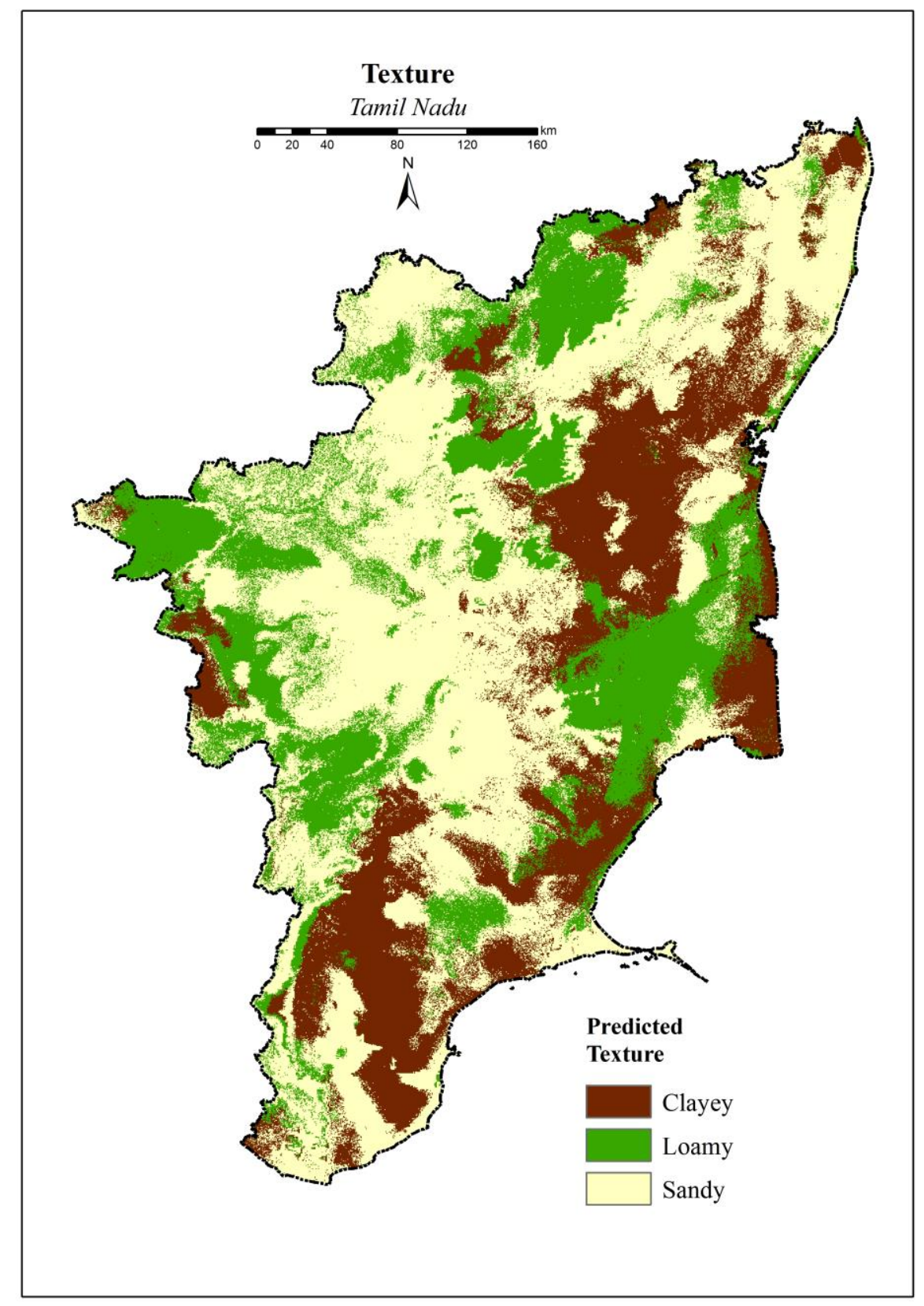

Fig. 5. Surface soil textural map of Tamil Nadu 


\section{References:}

426Abraham S, Huynh C, Vu H (2020) Classification of Soils into Hydrologic Groups Using Machine 427 Learning. Data 5: 2. doi:10.3390/data5010002

428Adhikari K, Kheir RB, Greve MB, Bøcher PK, Malone BP, Minasny B, McBratney AB, Greve MH 429 (2013) High-resolution 3-d mapping of soil texture in Denmark. Soil Sci Soc Am J 77: $430 \quad 860-876$

431Akpa SIC, Odeh IOA, Bishop TFA, Hartemink AE (2014) Digital mapping of soil particle-size 432 fractions for Nigeria. Soil Sci Soc Am J 78: 1953-1966

433Arrouays D, Grundy MG, Hartemink AE, Hempel JW, Heuvelink GBM, Hong SY, Lagacherie P, 434 Lelyk G, McBratney AB, McKenzie NJ, Mendonça-Santos MD, Minasny B, Montanarella L, 435 Odeh IOA, Sanchez PA, Thompson JA, Zhang GL (2014) GlobalSoilMap: towards a fine436 resolution global grid of soil properties. Advances in Agronomy 125: 93-134

437Bonfatti BR, Hartemink AE, Giasson E, Tornquist CG, Adhikari K (2016) Digital mapping of soil 438 carbon in a viticultural region of Southern Brazil. Geoderma 261: 204-221. $439 \quad$ http://dx.doi.org/10.1016/j.geoderma.2015.07.016

440Breiman L (2001) Random forests. Machine Learn. $441 \quad$ https://doi.org/10.1023/A:1010933404324

442Byrt T, Bishop J, Carlin JB (1993) Bias, prevalence and kappa. Journal of Clinical Epidemiology $443 \quad 46(5): 423-429$

444Camera C, Zomeni Z, Noller JS, Zissimos AM, Christoforou IC, Bruggeman A (2017) A high445 resolution map of soil types and physical properties for cyprus: A digital soil mapping 446 optimization. Geoderma 285: 35-49, https://doi.org/10.1016/j.geoderma.2016.09.019 
447Carrizo ME, Alesso CA, Cosentino D, Imhoff S (2015) Aggregation agents and structural 448 stability in soils with different texture and organic carbon contents. Scientia Agricola $449 \quad 72: 75-82$

450Chagas CDS, Junior WDC, Bhering SB, Filho BC (2016) Spatial prediction of soil surface texture 451 in a semi-arid region using random forest and multiple linear regressions. Catena 139: $452 \quad 232-240$

453Chan HC, Chang CH, Chen PA, Lee JT (2019) Using multinomial logistic regression for 454 prediction of soil depth in an area of complex topography in Taiwan. Catena 176: 419$455 \quad 429$

456Cohen J (1960) A coefficient of agreement for nominal scales. Educ Psychol Meas 20: 37-46 457Congalton RG, Green K (1998) Assessing the Accuracy of Remotely Sensed Data: Principles and $458 \quad$ Practices. CRC/Taylor \& Francis, Boca Raton, USA

459Demattê JAM, Alves MR, Terra F da S, Bosquilia RWD, Fongaro CT, Barros PP da S (2016) Is It 460 Possible to Classify Topsoil Texture Using a Sensor Located $800 \mathrm{~km}$ Away from the 461 Surface? Revista Brasileira de Ciência do Solo, 40, e0150335

462Dharumarajan S, Hegde R, Singh SK (2017) Spatial prediction of major soil properties using 463 Random Forest techniques-a case study in semi-arid tropics of South India. Geoderma $464 \quad$ Regional, 10:154-162

465Dharumarajan S, Kalaiselvi B, Lalitha M, Vasundhara R, Rajendra Hegde (2021) Defining 466 fertility management units and land suitability analysis using digital soil mapping 467 approach. Geocarto International. https://doi.org/10.1080/10106049.2021.1926553 468Dharumarajan S, Kalaiselvi B, Suputhra A, Lalitha M, Hegde R, Singh SK, Lagacherie P (2020) 469 Digital soil mapping of key GlobalSoilMap properties in Northern Karnataka Plateau. 

mol.com/paperRedirect/1307836545166970880

472Dharumarajan S, Vasundhara R, Suputhra A, Lalitha M, Hegde R (2020a) Prediction of soil 473 depth in Karnataka using digital soil mapping approach. Journal of Indian Society of $474 \quad$ Remote Sensing 48(11): 1593-1600

475Dharumarajan S, Hegde R (2020b) Digital mapping of soil texture classes using Random Forest 476 classification algorithm. Soil Use and Management. 477 https://doi.org/10.1111/sum.12668

478Dharumarajan S, Hegde R, Janani N, Singh SK (2019) The need for digital soil mapping in India. 479 Geoderma Regional, https://doi.org/10.1016/i.geodrs.2019.e00204

480Boroujeni EI, Shahini-Shamsabadi M, Shirani H, Mosleh Z, Bagheri-Bodaghabadi M, Salehi MH 481 (2020) Assessment of different digital soil mapping methods for prediction of soil 482 classes in the Shahrekord plain, Central Iran. Comparison of error and uncertainty of 483 decision. Catena 193, 104648

484Florinsky I, Eilers R, Manning G, Fuller L (2002) Prediction of soil properties by terrain 485 modeling. Environmental Modelling and Software 17(3): 295-311

486Gessler PE, Moore ID, McKenzie NJ, Ryan PJ (J 1995) Soil landscape modelling and spatial 487 prediction of soil attributes. Int Geogr Inf Syst, 9: 421- 432. $488 \quad$ doi:10.1080/02693799508902047

489Gribb M, Forkutsa I, Hansen AJ, Chandler D, McNamara J (2009) The effect of various soil 490 hydraulic property estimates on soil moisture simulations. Vadose Zone J 8:321 - 331. 491 doi:10.2136/vzj2008.0088 
492Grimm R, Behrens T, Märker M, Elsenbeer H (2008) Soil organic carbon concentrations and 493 stocks on Barro Colorado Island-digital soil mapping using random forests analysis. $494 \quad$ Geoderma 146: 102-113. http://dx.doi.org/10.1016/j. geoderma. 2008.05.008

495Hengl T, Heuvelink GBM, Stein A (2004) A generic framework for spatial prediction of soil 496 variables based on regression-kriging. Geoderma 120: 75-93

497Hengl T, Miller MAE, Križan J, Shepherd KD, Sila A, Kilibarda M, Antonijević O, Glušica L, 498 Dobermann A, Haefele SM, McGrath SP, Acquah GE, Collinson J, et al (2021) African soil 499 properties and nutrients mapped at $30 \mathrm{~m}$ spatial resolution using two-scale ensemble 500 machine learning. Sci Rep, 11: 6130. https://doi.org/10.1038/s41598-021-85639-y

501Heung B, Bulmer CE, Schmidt MG (2014) Predictive soil parent material mapping at a regional502 scale: a Random Forest approach. Geoderma 214-215, 141-154. 503 http://dx.doi.org/10.1016/j.geoderma.2013.09.016.

504Heuvelink GB (2013) Uncertainty quantification of GlobalSoilMap products. Glob Basis Glob 505 Spat soil Inf Syst: $327-332$

506Hillel D (1980) Applications of Soil Physics. Academic Press Inc 507Jenny H (1941) Factors of Soil Formation: A Quantitative System in Pedology, 281 pp, McGraw$508 \quad$ Hill, New York

509Kalaiselvi B, Lalitha M, Dharumarajan S, Srinivasan R, Rajendra Hegde, Anil Kumar KS, Singh SK 510 (2019) Fertility capability classification of semi-arid upland soils of Palani block, Tamil 511 Nadu for sustainable soil management. Indian Journal of Soil Conservation 47 (3): 143 512 147 
513Katerji N, Mastrorilli M (2009) The effect of soil texture on the water use efficiency of irrigated 514 crops: Results of a multi-year experiment carried out in the Mediterranean region. 515 European Journal of Agronomy 30(2): 95-100. doi:10.1016/j.eja.2008.07.009 516Kettler TA, Doran JW, Gilbert TL (2001) Simplified method for soil particle-size determination 517 to accompany soil-quality analyses. Soil Science Society of America Journal 65: 849$518 \quad 852$

519Kong X, Dao TH, Qin J, Qin H, Li C, Zhang F (2009) Effects of soil texture and land use 520 interactions on organic carbon in soils in North China cities' urban fringe. Geoderma 521 154(1-2): 86-92. doi:10.1016/j.geoderma.2009.09.016

522Kuriakose SL, Devkota S, Rossiter DG, Jetten VG (2009) Prediction of soil depth using 523 environmental variables in an anthropogenic landscape, a case study in the Western $524 \quad$ Ghats of Kerala, India. Catena 79(1): 27-38

525Lacoste M, Minasny B, McBratney A, Michot D, Viaud V, Walter C (2014) High resolution 3D 526 mapping of soil organic carbon in a heterogeneous agricultural landscape. Geoderma $527 \quad 213: 296-311$

528Lagacherie P, Arrouays D, Bourennane H, Gomez C, Martin M, Saby NP (2019) How far can the 529 uncertainty on a Digital Soil Map be known? A numerical experiment using pseudo 530 values of clay content obtained from Vis-SWIR hyperspectral imagery. Geoderma 337: $531 \quad 1320-1328$

532Lagacherie P, McBratney AB (2007) Spatial soil information systems and spatial Soil inference 533 systems: perspectives for digital soil mapping. In: Lagacherie P, McBratney AB, Voltz M 534 (Eds), Digital Soil Mapping: An Introductory Perspective. Elsevier BV. hlm, The $535 \quad$ Netherlands, pp. 3-22 
536Ließ M, Glaser B, Huwe B (2012) Making use of the World Reference Base diagnostic horizons 537 for the systematic description of the soil continuum - application to the tropical 538 mountain soil-landscape of southern Ecuador. Catena 97: 20-30

539Lu Y, Liu F, Zhao Y, Song X, Zhang G (2019) An integrated method of selecting environmental $540 \quad$ covariates for predictive soil depth mapping. Journal of Integrative Agriculture 18: 301541 315. https://doi.org/10.1016/S2095-3119(18)61936-7

542Mashalaba L, Galleguillos M, Seguel O, Poblete-Olivares J (2020) Predicting spatial variability of 543 selected soil properties using digital soil mapping in a rainfed vineyard of central Chile. $544 \quad$ Geoderma Regional 22, e00289

545Malone B, Minasny B, Odgers N, McBratney AB (2014) Using model averaging to combine soil 546 property rasters from legacy soil maps and from point data. Geoderma 232-234, 34-44 547Malone BP, Luo Z, He D, Rossel RAV, Wang E (2020) Bioclimatic variables as important spatial 548 predictors of soil hydraulic properties across Australia's agricultural region. Geoderma 549 Regional, e00344. doi:10.1016/j.geodrs.2020.e00344

550McBratney AB, Mendonca-Santos ML, Minasny B (2003) On digital soil mapping. Geoderma 551 117: 3-52. https://doi.org/10.1016/S0016-7061(03)00223-4

552Mehnatkesh A, Ayoubi S, Jalalian A, Sahrawat KL (2013) Relationships between soil depth and 553 terrain attributes in a semi-arid hilly region in western Iran. J Mt Sci, 10 (1): 163-172

554Mehrabi-Gohari E, Matinfar HR, Jafari A, Taghizadeh-Mehrjardi R, Triantafilis J (2019) The 555 Spatial Prediction of Soil Texture Fractions in Arid Regions of Iran. Soil System 3: 65 556Minasny B, McBratney AB (2016) Digital soil mapping: a brief history and some lessons. $557 \quad$ Geoderma 264: 301-311 
558Mitran T, Mishra U, Lal R, Ravisankar T, Sreenivas K (2018) Spatial distribution of soil carbon 559 stocks in a semi-arid region of India. Geoderma Regional, e00192 560 https://doi.org/10.1016/j.geodrs.2018.e00192

561Mosleh Z, Salehi MH, Jafari A, Borujeni IE, Mehnatkesh A (2016) The effectiveness of digital soil 562 mapping to predict soil properties over low-relief areas. Environmental Monitoring and 563 Assessment, 188 (195). http://dx.doi.org/10.1007/s10661-016-5204-8

564Natarajan A, Reddy PSA, Sehgal J, Velayutham M (1997) Soil Resources of Tamil Nadu for Land 565 Use Planning. NBSS Publ 46b (Soils of India series) National Bureau of Soil Survey and $566 \quad$ Land Use Planning, Nagpur, India p. $88+4$ sheet soil map 1:500,000 scale 567Nussbaum M, Spiess K, Baltensweiler A, Grob U, Keller A, Greiner L, Schaepman ME, Papritz A 568 (2018) Evaluation of digital soil mapping approaches with large sets of environmental 569 covariates. Soil 4:1-22. https://doi.org/10.5194/soil-4-1-2018, 2018

5700deh IOA, Chittleborough DJ, McBratney AB (1991) Elucidation of soil-landform 571 interrelationships by canonical ordination analysis. Geoderma 49:1-32

572Reddy NN, Chakraborty P, Roy S, Singh K, Minasny B, McBratney AB, Biswas A, Das BS (2021) 573 Legacy data-based national scale digital mapping of key soil properties in India. 574 Geoderma. https://doi.org/10.1016/i.geoderma.2020.114684

575Rudiyanto, Minasny B, Setiawan BI, Arif C, Saptomo SK, Chadirin Y (2016) Digital mapping for 576 cost-effective and accurate prediction of the depth and carbon stocks in Indonesian 577 peatlands. Geoderma 272: 20-31

578Senagi K, Jouandeau N, Kamoni P (2017) Using parallel random forest classifier in predicting 579 land suitability for crop production. Journal of Agricultural Informatics 8(3): 23-32. $580 \quad$ https://doi.org/10.17700/jai.2017.8.3.390 
581Shivaprasad CR, Reddy RS, Sehgal J, Velayutham M (1998) Soils of Karnataka for optimizing 582 land use. NBSS\&LUP publication No.47b, Nagpur

583Silva BPC, Silva MLN, Avalos FAP, Menezes MDD, Curi N (2019) Digital soil mapping including 584 additional point sampling in Posses ecosystem services pilot watershed, southeastern 585 Brazil. Sci Rep Nat 9, 13763

586Soil Survey Staff (2014) Soil taxonomy: a basic systems of soil classification for making and 587 interpreting soil surveys (Twelfth ed). USDA, NRCS

588Sreenivas K, Dadhwal VK, Kumar S, Harsha GS, Mitran T, Sujatha G, Suresh GJR, Fyzee MA, 589 Ravisankar T (2016) Digital mapping of soil organic and inorganic carbon status in 590 India. Geoderma 269: 160-173. https://doi.org/10.1016/j.geoderma.2016.02.002

591Story M, Congalton R (1986) Accuracy assessment: A user's perspective. Photogrammetric $592 \quad$ Engineering and Remote Sensing 52:397-399

593Tesfa TK, Tarboton DG, Chandler DG, McNamara JP (2009) Modelling soil depth from 594 topographic and land cover attributes. Water Resources Research 45, W10438. 595 https://doi.org/10.1029/2008WR007474

596Thompson JA, Roecker S, Grunwald S, Owens PR (2012) Digital soil mapping: Interactions with 597 and applications for hydropedology, In Hydropedology, edited by: Lin H, Academic $598 \quad$ Press, Boston, 665-709

599Tola E, Al-Gaadi KA, Madugundu R, Zeyada AM, Kayad AG, Biradar CM (2017) Characterization 600 of spatial variability of soil physicochemical properties and its impact on Rhodes grass 601 productivity. Saudi Journal of Biological Sciences 24(2): 421-429. 602 doi:10.1016/j.sjbs.2016.04.013 
603Tsai CC, Chen ZS, Duh CT, Horng FW (2001) Prediction of soil depth using a soil landscape 604 regression model: a case study on forest soils in southern Taiwan. National Science 605 Council of the Republic of China. Part B- Life Sciences 25(1): 34-39

606Vågen TG, Winowiecki LA, Tondoh JE, Desta LT, Gumbricht T (2016) Mapping of soil properties 607 and land degradation risk in Africa using MODIS reflectance. Geoderma 263: 216-225

608Vaysse K, Lagacherie P (2015) Evaluating digital soil mapping approaches for mapping 609 GlobalSoilMap soil properties from legacy data in Languedoc-Roussillon (France). 610 Geoderma Regional 4: 20-30

611Vaysse K, Lagacherie P (2017) Using quantile regression forest to estimate uncertainty of 612 digital soil mapping products. Geoderma 291: 55-64. $613 \quad$ https://doi.org/10.1016/i.geoderma.2016.12.017

614Viscarra Rossel RA, Webster R, Bui EN, Baldock JA (2014) Baseline map of organic carbon in 615 Australian soil to support national carbon accounting and monitoring under climate 616 change. Glob Chang Biol 20: 2953-2970

617Wilding L (1985) Spatial variability: its documentation, accommodation and implication to soil 618 surveys. In Soil Spatial Variability Workshop, 166-194

619Zeraatpisheh M, Ayoubi S, Jafari A, Tajik S, Finke P (2019) Digital mapping of soil properties 620 using multiple machine learning in a semiarid region, central Iran. Geoderma 338: 445621 452. https://doi.org/10.1016/i.geoderma.2018.09.006

622Zhang M, Shi W, Xu Z (2020) Systematic comparison of five machine-learning models in 623 classification and interpolation of soil particle size fractions using different transformed 624 data. Hydrology and Earth System Science 24: 2505-2526. 625 https://doi.org/10.5194/hess-24-2505-2020 
626

627 